\title{
Management of the red palm weevil Rhynchophorus ferrugineus (Olivier) using sustainable options in Saudi Arabia
}

\author{
M. Ali-Bob \\ Al-Mohamadia Dates Co., P.O. Box 66510, Riyadh 11586, Saudi Arabia, email: malibobs@yahoo.com
}

\begin{abstract}
Ali-Bob, M. 2019. Management of the Red Palm Weevil Rhynchophorus ferrugineus (Olivier) using sustainable options in Saudi Arabia. Arab Journal of Plant Protection, 37(2): 163-169.

Adhering to sustainable date farming practices in Al-Mohamadia farm in Al-Kharj region of Saudi Arabia has resulted in increased date fruits production by 2 fold in a 3 year time span from mature date palm trees grown on sandy soils and employing modern irrigation systems. The quality of date fruits has improved dramatically. The irrigation regime adopted resulted in enhanced water use efficiency and had a positive impact on date yield and fruit quality improvement. Among 20 date palm cultivars grown in Al- Mohamadia farm, 'Sagae' cultivar and male trees from different age groups were found to be more susceptible to RPW infestations. On-farm management practices of date palm pests particularly the notorious red palm weevil Rhynchophorus ferrugineus (Olivier) is presented. Control efforts against the RPW focused on the use of a blend of tactics including visual inspection and pheromone trapping, prevention and suppression through field sanitation, cultural practices, mechanical methods, eradication of severely infested palm trees, and chemical injection of Emamectin benzoate insecticide, which has shown good and long lasting effect. Steinernema carpocapsae (Weiser) nematodes alone or in combination with a local strain of Beauveria bassiana Bals. using trunk injections to control RPW showed mixed results. Some of red palm weevil management challenges, from a farmer's perspective were discussed.

Keywords: Date palm, red palm weevil, Rhynchophorus ferrugineus, IPM.
\end{abstract}

\section{Introduction}

The date palm, Phoenix dactylifera L. (Arecales: Arecaceae) trees are an important economic resource for many communities particularly in the Middle East and North Africa. Palms provide great cultural, social and environmental value. In Southern Europe, exotic palm trees are an essential component of the urban landscape. The Arab Region dominates in date production and trade. About 75\% of the global area of 1.35 million ha under date palm is in the Arab Region (FAOSTAT, 2016). The Arab Region produces more than $75 \%$ of the world production of 8.46 million Tons of date. However, the date palm sector faces many production and marketing constraints including pests and diseases. El-Shafie (2012) enlisted 112 species of insects and mites associated with date palm worldwide. Losses in global production of dates have been estimated at $30 \%$ due to pests and diseases (FAOSTAT, 2013).

Date palm is very important in the socio-economy of people in Saudi Arabia. In 2015, the total tree count in Saudi Arabia was 28,570,804 grown in 123,301 farm holdings in an area of 107,281 Ha (General Authority for Statistics, KSA, 2015). Saudi Arabia is reported to have over 400 date palm cultivars of which 25 are important (Anonymous, 2006; Ashraf and Hamidi Esfahani, 2011). Dates production of Saudi Arabia averaged 970,000 tons during 2007-2016 (FAOSTAT, 2016). In 2016 Saudi Arabia exported 116,993 tons of dates worth aroud 141 million USD representing 9.8\% of total value of global date exports (UN comtrade, 2018). In the National Transformation Program of Saudi Arabia's Vision 2030, the Kingdom is targeting a sales volume of about USD 2.45 billion (Vision 2030) to be achieved through sustainable development of the date palm value chain.

The Red Palm Weevil (RPW), Rhynchophorus ferrugineus (Olivier) (Coleoptera: Curculionidae) is the most destructive pest of palms. FAO has designated it as category1 pest on date palm in the Middle-East. It has a wide geographical and host range causing widespread damage to some 40 palm species in diverse agro-ecosystems worldwide (Anonymous, 2013). It has currently been reported in 45 countries (Faleiro and Al-Shawaf, 2018). R. ferrugineus was first reported in AlQatif in the Eastern Province of Saudi Arabia in 1987 (Abozuhairah et al., 1996). The effects of the RPW and the measures required to eradicate and control it are having significant socio-economic and environmental impacts on the palm production communities worldwide. The annual loss in six Gulf countries due to eradication of severely infested palms has been estimated to range from US\$ 5.18 million to US\$ 25.92 million at 1 and 5\% infestation, respectively (El-Sabea et al., 2009). Saudi Arabia's vision 2030 program is targeting to bring the level of RPW infestation from currently estimated $10 \%$ to $1 \%$. Toward this end the Ministry of Environment, Water and Agriculture of the Kingdom of Saudi Arabia (MEWA) has embarked on an intensive nationwide RPW management program.

\section{Date Palm Crop Management Practices in Al- Mohamadia Farm}

Al-Mohamadia model farm (MF) is a model date palm farm and a leading production and dates processing company in Saudi Arabia. The farm is located in Al Kharj region, about 
$60 \mathrm{~km}$ to the south of the capital Riyadh. MF has around 30,000 mature date palm trees comprising 20 date palm cultivars, including 'Khalas', 'Sagae', 'Khodri', 'Nabtat Saif', 'Nabtat Sultan' and 'Hilali'. The dates are grown in sandy loamy soil with relatively elevated salinity level. Soil $\mathrm{pH}$ ranged from 7.1 to 8.2 and $\mathrm{EC}$ ranged from 3 to 14 ms/cm. The $\mathrm{CaCo}_{3}$ content was relatively high (10-20\%). The water quality is of the second degree with TDS ranging from 986 to 2,500 and $\mathrm{pH}$ of around 7.5 which was suitable for date palm production. MF dates are produced in accordance with optimized technical procedures and modern date palm technical operations.

MF adopts standard husbandry and GAP practices and site specific management practices in fertilization to maintain soil fertility, manage pests and apply modern irrigation systems to enable date production at high yield and quality specifications. Standard date palm ground and crown technical operations i.e. spiking, traditional pollination, fruit bunch thinning, offshoots removal, leaf and trunk pruning, bunch lowering and support, fruit bunch bagging, harvesting, sorting and storage were properly performed.

MF adopts a drip irrigation system and since 2013 implementing a watering regime that takes in consideration the factors of climate, soil type, tree age, variety and crop developmental stage. MF irrigation regime considers multiple measures including less irrigation time/tree but more irrigation frequency, particularly in farm blocks with sandy soil, improved water distribution in tree basin by using more bubblers/tree basin, improved water retention in tree basin through the use of organic manure, adapted flexible watering regime throughout the season according to soil type, date palm cultivar, climatic conditions and fruit developmental stage. During the period 2013 to 2017, there has been a general trend of yield increase as irrigation volume increased (Table 1). Monthly water applied ranged from 4.0 to 14.4 cubic meters per tree. Applying up to 121 cubic meter per year per mature date palm tree had a great impact on fruit yield and has contributed positively to fruit quality thus more farm revenues. Although fruit quality is a function of multiple management practices including thinning regime and the fertilization program. During the period 2013-2017, WUE in MF ranged from 0.59 to 0.82 $\mathrm{Kg} / \mathrm{m}^{3}$. Water footprint has been reasonably low ranging from 1,222 to $1,701 \mathrm{~m} 3 /$ ton, while the revenue was high and ranged 1,140 to $1,460 \mathrm{USD} /$ ton (Table 1). Apparently this is influenced by market date price which is a function of fruit quality in addition to other market dynamics. Prices of 'Khalas' date fruits which is the predominant cultivar in MF
(61\% of the number of trees and $60 \%$ of yield volume) has been generally declining in the reported period.

During the period 2014-2017, date palms in MF received an average of 1.2 units of nitrogen, 0.5 units of phosphorus and 1.4 units of potassium in addition to varying quantities of calcium, magnesium, sulphur and some other minor elements. These units were availed from multiple sources including compost, farm yard manures, urea, ammonium sulphate, DAP, potassium sulphate, magnesium sulphate, calcium nitrate and potassium nitrate in addition to various granular and soluble compound fertilizers including 16-8-16 and 12-12-17 and small quantities of micro and trace element nutrient mixes. The type and amounts of fertilizers applied differed from one season to another. A major fertilizer meal composed of $25-50 \mathrm{Kg}$ of organic manure plus DAP, potassium sulphate and magnesium sulphate were applied (incorporated in the soil) in Nov-Dec. The balances of fertilizer recipes were distributed throughout the active growing season from March to July with significant part of the potassium units applied during mid to late 'khalal' stage.

In $\mathrm{MF}$, the pest management program dealt with fighting the fruit worms, mainly the lesser date moth, Batrachedra amydraula (Meyrick) with one prophylactic application immediately after completion of fruit setting (March-April), using generic pyrethroids e.g. Deltamethrins, Cypermethrins, Alphacypermethrins, Betacyfluthrins and Lambdacyhalothrin insecticides. Mites, mainly the old world date mite Oligonychus afrasiaticus McGreg., was one of the most notorious pests which required timely intervention with an average of 2.5 applications in the season using Abamectins, Flufenoxuron, Fenbutatin oxide, Hexythiazox, Matrine, Spirodiclofen, Spiromesifen, chlorfenapyr and mineral oils. Some of these chemicals are banned and no longer approved for use in Saudi Arabia. Fruit stalk borer, Rhinoceros beetles (Oryctes spp.) and longhorn borer Jebusaea hammerschmidti Reich were of less importance and were controlled using light traps. Synthetic pyrethroids were seldom used against these borers.

Fruit spots and sporadic incidences of heart rots were not of significance and were rarely combated using tebecunazole and triademeonle fungicides. Chemical pesticides were used in an alternating way to cater for resistance development. Other date palm pests and diseases e.g. Dubas bug, Ommatissus binotatus Fieber, green pit scale, Palmapsis phoenicis Rao, carob moth, Ectomyelois ceratoniae (Zeller) were of least importance.

Table 1. Irrigation and water use efficiency in Al-Mohamadia farm during the period 2013-2017.

\begin{tabular}{|c|c|c|c|c|c|}
\hline Year & $\begin{array}{c}\text { Yield } \\
\text { (Kg/ tree) }\end{array}$ & $\begin{array}{c}\text { Water applied } \\
\left(\mathrm{m}^{3} / \text { tree }\right)\end{array}$ & $\begin{array}{c}\text { WUE } \\
\left(\mathbf{K g} / \mathbf{m}^{3}\right)\end{array}$ & $\begin{array}{c}\text { Water footprint } \\
\left(\mathrm{m}^{3} / \text { ton }\right)\end{array}$ & $\begin{array}{c}\text { Revenue } \\
(\mathbf{1 , 0 0 0} \text { USD/ton) }\end{array}$ \\
\hline 2013 & 46.92 & 60.00 & 0.78 & 1,279 & 1.35 \\
\hline 2014 & 52.00 & 88.47 & 0.59 & 1,701 & 1.22 \\
\hline 2015 & 87.84 & 121.39 & 0.72 & 1,382 & 1.20 \\
\hline 2016 & 79.96 & 119.13 & 0.67 & 1,490 & 1.46 \\
\hline 2017 & 90.84 & 110.98 & 0.82 & 1,222 & 1.14 \\
\hline
\end{tabular}


Bunch decline disorder striking during late 'Khalal' stage have been occasionally recorded in some seasons, more particularly on 'Sukkari' and 'Sellaj' cultivars, especially in trees with heavy fruit set in high temperature seasons. Nonchemical weeding was performed during the period from November to May. Weeds were left untouched from June until end of date fruits harvest by end of October.

This practice proved to be helpful in modifying the date palm tree microclimate to mitigate the excessive heat during summer. The use of mechanical cultivators (two-wheel 10.7 hp tilling machine) for weeding proved to be useful. In addition to removal of weeds, soil aeration, the use of cultivators helped to incorporate organic material in the tree basin. Weeding using cultivators proved to be more efficient compared to manual weeding and has positively reflected in tree performance. Timely harvesting of date fruits once they are ready for picking, helped in reducing incidence of insect infestations. However, high insect infestation in late maturing cultivars e.g. 'Munifi' could not be avoided and the fruits had to be fumigated afterwards.

The adoption of improved irrigation, fertilization, pest management, technical crown operations, cultural practices and farm team motivation has led to achieving outstanding farm key performance indicators. The adopted measures resulted in increased date fruits production by more than two folds. Average date palm tree yield increased from $39.4 \mathrm{Kg}$ in 2012 to $87.8 \mathrm{Kg}$ and $90.8 \mathrm{Kg}$ in 2015 and 2017 seasons, respectively (Table 2). The drop to $80.0 \mathrm{Kg} /$ tree has been a result of a more rigorous fruit bunch thinning regime adopted in 2016 season. The quality of date fruits has also improved dramatically. The percentage of big fruits (Royal and Premium) increased from 33\% in 2012 to 38\%, 59\%, and $55 \%$ in 2013, 2014, 2016, respectively (Table 2). The proportion of big fruits dropped to only $28 \%$ in 2015 and only $25 \%$ in 2017 , apparently due to the significant increase in yield (Table 2) as a result of a relaxed thinning regimes in 2015 and 2017 seasons.

\section{RPW Incidence and Management Practices in Al-Mohamadia Farm}

$R$. ferrugineus can be managed by adopting an integrated pest management strategy including regulatory methods, behavior manipulation, chemical and biological control, crop and field sanitation, eliminating hidden breeding sites, manipulation of cultural practices (Al-Dosary et al., 2016). Studies in Saudi Arabia have shown that the date palm farming practices adopted, the variety planted, method of irrigation, palm density, crop and field sanitation, frond pruning, and offshoot removal, significantly affected the establishment and subsequent infestation level of red palm weevil in date palm (Sallam et al., 2012). Periodic inspections, although laborious, time consuming and costly have been carried out for detection of damage symptoms and weevil presence in the crown, the stipe, among the offshoots and around the palm base. General tree decline and leaf yellowing symptoms were helpful indicators to direct the surveillance team to do closer inspections. The level of RPW infestation in MF blocks and within the same block appeared to be clumped rather than uniform or random. Regular inspection of palms to detect early infestations in order to take appropriate measures early is becoming increasingly important and is now known to be the most essential component of the IPM strategy against $R$. ferrugineus (Faleiro and Al-Shawaf, 2018). Pilot trials on the use of thermal imaging, hyperspectral and Lidar for RPW detection were conducted in MF during 2016-2017 in collaboration with TEC-IB co. of the Netherlands and the Saudi Technology Development and Investment Company (TAQNIA). Preliminary promising results have been obtained, however further optimization is required.

RPW accumulated infestation incidences were $2.83 \%$, $2.41 \%, 2.42 \%$ and $2.14 \%$ in 2014, 2015, 2016 and 2017, respectively. 'Sagae' cultivar and male trees from different age groups were found to be more susceptible to RPW infestation compared to other date palm cultivars grown in MF. This could be due to some physical or chemical characteristics or due to the presence/absence of fungal endophytic communities. Al-Bagshi et al. (2013) reported that 'Khalas' is among the most preferred date palm cultivars for egg laying by RPW. Contrary to many reports that showed highest infestation in young age groups, we have recorded higher RPW infestations in MF blocks with age group of 35-45 years than in blocks where the tree age was about 22-25 years. In coconut and date palm, young palms less than 20 years old are mostly infested by RPW (Abraham et al., 1998; Faleiro, 2006) indicating that tissue hardness, which increases with palm age, may deter RPW attack. According to Khalifa et al. (2001), 6-10 years old palm trees were more susceptible to infestation as compared to any other age group. Date palms 16 and more years old, are more resistant to infestation. Farazmand (2002) and Al-Ayedh (2008) found that date palm cultivars with high sugar content enhanced RPW population.

Table 2. Al-Mohamadia farm: total date yield in $\mathrm{Kg}$ (2012-2017).

\begin{tabular}{lcccccc}
\hline & $\mathbf{2 0 1 2}$ & $\mathbf{2 0 1 3}$ & $\mathbf{2 0 1 4}$ & $\mathbf{2 0 1 5}$ & $\mathbf{2 0 1 6}$ & $\mathbf{2 0 1 7}$ \\
\hline Number of trees & 30,995 & 30,780 & 30,464 & 30,222 & 30,017 & 29,837 \\
Total yield $(\mathrm{Kg})$ & $1,220,060$ & $1,444,144$ & $1,584,181$ & $2,654,568$ & $2,400,078$ & $2,710,487$ \\
Average yield/tree $(\mathrm{Kg})$ & 39.4 & 46.9 & 52.0 & 87.8 & 80.0 & 90.8 \\
\% Big fruits & 33 & 38 & 59 & 28 & 55 & 25 \\
\% Small fruits & 67 & 62 & 41 & 72 & 45 \\
\hline
\end{tabular}


In MF, while RPW infestations occurred in tree trunks, however in 'Sagae' cultivar and male trees, infestations occurred mostly at the tree crown. The infestation rate of palm trees that warranted eradication ranged from $25 \%$ to $28 \%$ (Table 3). The proportion of severely infested date palm trees which were eradicated were higher in 'Sagae' and male trees compared to 'Khalas' and other palm trees in which infestations occured at the tree trunk. When infestation is in the trunk the recovery chances seemed to be higher. Abraham et al. (2000) found that eradication of severely infested palms detected in area-wide pheromone based RPW-IPM programs in the Al Hassa oasis of KSA from 1995 to 1997 to stabilize at around $20 \%$, whereas the remaining infestations responded to treatment with insecticide. Infestation at the height of $0-100 \mathrm{~cm}$. was significantly more as compared to infestation occurring at any other height. Infestation recorded higher than one meter, was negligible (Khalifa et al., 2001). In date palm, infestation mostly occured at the base of the trunk near the soil (Abraham et al., 1998; Sallam et al., 2012), whereas in Phoenix canariensis the crown of the palm is usually attacked making detection extremely difficult and challenging (Dembilio and Jacas, 2012). Relatively high level of infestations were recorded in block 14 in MF which happened to be adjacent to the dumping area for eradicated RPW stricken trees; suggesting the inefficiency of RPW control even after burning of dead trunks. This highlights the importance of burial of dead trees after complete burning and preferably shredding.

\section{Chemical Control of RPW in Al-Mohamadia Farm}

In MF, major pest management efforts were directed towards RPW. Newly infested trees when detected, were clearly marked, and immediately sanitized by mechanically eliminating reachable insects and infested/damaged trunk tissues. This is followed by spraying with an insecticide and sealing the wound with Gypsum. Treating with diesel following offshoot removal was also a practice followed in MF. Other preventive and curative chemical treatments including chemical spraying and drenching in water and trunk injection with systemic insecticides were carried out in MF. At least one prophylactic chemical spraying in Dec. and/or March were directed at the crown of 'Sagae' cultivar and male trees in which the RPW infestations occured at the tree crown. Chemicals used for frond and trunk spraying included Fipronil, pyrethroids and Thiamethoxam insecticides. During the period 2015-2016, RPW infested palms were treated with Imidacloprid insecticide drenched in the tree basin at the rate of $21 \mathrm{gm}$ a.i./tree coupled with simultaneous spraying of palm leaves and trunk to take care of new infestations and pupating insects at the rate of $3.5 \mathrm{gm}$ a.i./tree. This treatment was repeated three time per year in the same tree with a one month interval, usually carried out in Feb, Mar and April. Imidacloprid application by this method yielded around $90 \%$ efficacy, however this treatment regime proved to be laborious and costly. Preliminary trials in 2017 showed that single trunk injection using Imidacloprid at the rate of $15 \mathrm{gm}$ a.i./tree yielded more or less similar results and protected the palms for up to three months. Stem injection of Imidacloprid has been reported to cause more than $90 \%$ mortality in young grubs for more than 2 months after treatment (Dembilio et al., 2015; Dembilio and Jaques, 2015).

During the period from Nov 2016 to Sep 2018 and following successful initial trials, single application of Revive $₫$ (Emamectin benzoate $4 \mathrm{ME}$ ) insecticide employing trunk injections have been adopted as the main curative chemical treatment. Revive ${ }^{\circledR}$ was applied at low pressure at the rate of $50 \mathrm{ml} /$ tree (undiluted formulation) administered in 4 holes drilled at the base of infested tree trunk. In MF, date palm trunk injection using Revive ${ }^{\circledR}$ have shown improved efficacy and long lasting PPW control up to 9 months after treatment. Following Revive ${ }^{\circledR}$ applications in 2017 and 2018, more RPW infestations were recorded in offshoots. Conventional aggregation pheromones and Electraps were used for mass trapping of RPW in MF. Pheromone traps at the rate of 2 traps per hectar were deployed in blocks with high weevil activity. Pheromone traps were placed away from farm borders to make sure that they do not contribute to attracting RPW from neighboring farms. Food baited pheromone traps are widely used to monitor and mass trap adult $R$. ferrugineus in date palm, where most weevil captures are females (Faleiro, 2006).

\section{Non-Chemical RPW Control in Al-Mohamadia Farm}

In MF there has been no introduction of new date palm planting material from outside the farm. RPW prevention and suppression revolved around field sanitation, cultural practices and mechanical methods. Crop and field sanitation is vital to curb the build-up of RPW population and to sustain the levels of success where the pest is controlled (Abraham et al., 1998; Al-Dosari et al., 2016). In MF, sanitation by mechanical elimination of infested palm tissues has been followed by prophylactic treatment of wounds and use of gypsum to seal sites of mechanical damage. Double ring irrigation basins were erected in some MF blocks to make sure that water not to be in direct contact with the base of the date palm trunk and associated offshoots, if any. Off-shoot removal is practiced as offshoots contact with mother palm trees may predispose the palm trees to RPW. Avoiding palm injuries was very crucial and sticking to concurrent protective spraying when doing stem pruning 'Takreeb' have been stressed in MF RPW management program. Severely infested palm trees which were beyond recovery were eradicated by burning. 
Table 3. Number of date palm trees infested and eradicated due to the red palm weevil infestation in Al-Mohamadia farm during the period $2014-2017$.

\begin{tabular}{lcccc}
\hline & $\mathbf{2 0 1 4}$ & $\mathbf{2 0 1 5}$ & $\mathbf{2 0 1 6}$ & $\mathbf{2 0 1 7}$ \\
\hline No. of palm trees & 30,464 & 30,222 & 30,017 & 29,837 \\
No. of infested palm trees & 861 & 728 & 726 & 640 \\
No. of eradicated palm trees & 242 & 205 & 180 & 165 \\
\% infestation & 2.83 & 2.41 & 2.42 & 2.14 \\
\% eradicated palm trees & 0.79 & 0.68 & 0.60 & 0.55 \\
\hline
\end{tabular}

\section{Non-chemical RPW control in Al-Mohamadia farm}

In MF there has been no introduction of new date palm planting material from outside the farm. RPW prevention and suppression revolved around field sanitation, cultural practices and mechanical methods. Crop and field sanitation is vital to curb the build-up of RPW population and to sustain the levels of success where the pest is controlled (Abraham et al., 1998; Al-Dosari et al., 2016). In MF, sanitation by mechanical elimination of infested palm tissues has been followed by prophylactic treatment of wounds and use of gypsum to seal sites of mechanical damage. Double ring irrigation basins were erected in some MF blocks to make sure that water not to be in direct contact with the base of the date palm trunk and associated offshoots, if any. Off-shoot removal is practiced as offshoots contact with mother palm trees may predispose the palm trees to RPW. Avoiding palm injuries was very crucial and sticking to concurrent protective spraying when doing stem pruning 'Takreeb' have been stressed in MF RPW management program. Severely infested palm trees which were beyond recovery were eradicated by burning. Date palms in the late stage of attack exhibiting severe tissue damage $(>30 \%)$ should be eradicated (Faleiro and Al-Shawaf, 2018). The entomopathogenic nematodes Steinernema carpocapsae (Weiser) alone or in combination with a local strain of Beauveria bassiana Bals. using trunk injections have been used in MF against the RPW and showed mixed results. It is important to further explore the potential of using these biological agents employing standardized protocols to consistently test and enable fair evaluation and judgement of their utility and true potential in the fight against the RPW under field conditions. Issues of formulation, delivery into to palm trees, mobility (if any) of entomopathogens inside tree trunk, persistence and the best time window for field application are some of the issues that need to be evaluated.

\section{On farm RPW challenges in Al-Mohamadia farm}

Even though significant progress was made in RPW management at MF, there are still a number of challenges that need to be addressed and they are as follows:

- Despite all efforts against RPW, there is still moderate efficiency of RPW management in Al-Mohamadia farm.

- Reinfestation of the same palm tree after treatment.
- The cost of RPW control in MF has been high and it is labor intensive.

- Application challenges, especially in case of trunk injections in large date palm plantations with high RPW incidence. The drilling, injection arrangements and sealing of holes are laborious.

- Delayed removal of severely infested palms and dispersal of insects en route to the dumping sites.

- Spread of infestation from not properly incinerated palm trees.

- Due to the cryptic nature of this pest, crown infestation in some cultivars proved to be challenging to inspection teams and symptoms were detected in an advanced stage when damage had already taken place and chances of recovery become low.

- Lack of a quick, cost effective and easy to handle device for early detection of RPW.

- The dissection of palm trees in trials and RPW control evaluations, has been laborious, time consuming and costly. Utilization of novel non-destructive early detection technologies are very much needed in this regard.

- Continuous replacement/servicing and inspection of the RPW conventional traps has been challenging.

- Lack of active and effective involvement of neighboring farmers in RPW control operations.

- Lack of effective natural/biological insecticides and thus more environmental and health hazard as a result of the frequent use of preventive and curative RPW insecticides.

\section{Concluding Remarks}

- In MF despite all RPW control efforts being exerted, the infestation levels are still high in some sections of the farm. The pest continues to inflict significant damage. This is partly due to presence of sources of infestation from neighboring farms. RPW are good flyers, they can fly up to $5 \mathrm{Km}$ and are capable of long range dispersal (Avalos et al. 2014), thus capable of crossing borders and reaching from farms many kilometers away.

- During a four year span, RPW infestation rate in MF date palm blocks ranged from $0 \%$ to around $11 \%$. Higher infestation rates were always recorded in blocks adjacent to neighboring farms and in one block adjacent to a dumping site, where eradicated palm trees are incinerated. 
- It is important to train and motivate field workers to carry out inspections and monitoring of RPW infestations and carefully inspect trees with multiple offshoots and to avoid palm injuries.

- If 'Takreeb' is to be done at all, then it should be done at time of low RPW activity and concurrent spraying with effective insecticides has to be carried out effectively and without delay.

- RPW incidence seems to be higher than generally anticipated. Given the cryptic nature of RPW, we suggest using an arbitrary on-farm RPW infestation rate to reflect a more realistic estimation of RPW incidence by multiplying the actually detected RPW infestation level by 3 .

- Date palm farmers work in isolation and there is a need for coordinated efforts through farmer cooperatives. There is a need for cooperation and coordination of efforts at all levels for development and implementation of a successful RPW IPM strategy.
- From a farmer's perspective we believe such an IPM strategy should utilize modern early detection technologies in addition to the use of an optimized attract and kill tool, while endotherapy treatments utilizing chemical/biological insecticides is to be adopted for controlling RPW in established infestations.

- It is important to establish propagation centers for dissemination of RPW free planting material of popular date palm cultivars in addition to adoption of phytosanitary and strict quarantine regulations. It is important to put in place effective modalities to ensure farmer and stakeholder participation in the RPW management programs.

- There is a need for quantification of the socioeconomic impact of RPW and evaluation of the risks associated with RPW at the national level.

\section{الملخص}

علي بوب، محمد. 2019. إدارة سوسة النخيل الحمراء Rhynchophorus ferrugineus Olivier باتبّاع خياراتٍ مستدامة في المملكة العربية

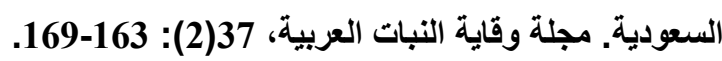

أثمر الالتز ام بممارسات الزر اعة المستدامة للنخيل في مزار ع المحمّدية الو اقعة ضمن منطقة الخرج في المملكة العربية السعودية زيادةً بلغت حو الي الضعفين

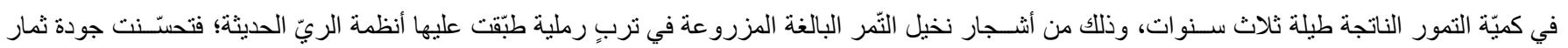

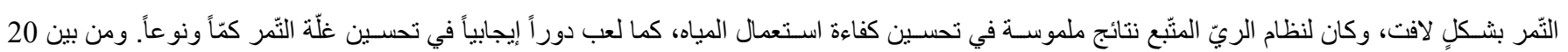

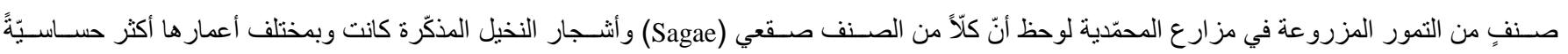

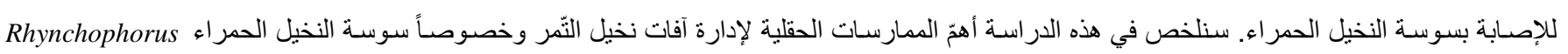
Olivier الفيرمونية، المنع والاعاقة من خلال اتبّاع تدابير نظافة الحقل، الممارسات الزراعية، الطر ائق الميكانيكية، استئصال أشجار النخيل المصابة بشدّة، والحقن الكيميائي بمبيد إيماكتين بنزوات والذي أظهر فعاليةً جيدة وتأثيراً مديداً، تم استخدام النيماتودا Steinernema carpocapsae (Weiser سواءً مفردةً أو بدمجها مع عزلةٍ محليّة لفطر البوفاريا Baulseria bassiana

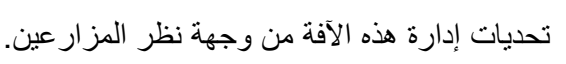
كلمات مفتاحية: نخيل التمر، سوسة النخيل الحمر اء، Rhynchophorus ferrugineus، برنامج المكافحة المتكاملة.

\section{References}

Abozuhairah, R.A., P.S.P.V, Vidyasagar and V.A. Abraham. 1996. Integrated management of red palm weevil, Rhynchophorus ferrugineus in date palm plantations of the Kingdom of Saudi Arabia. In Proc. XX Int. Congress of Entomol., edited by M. Biondi et al. (Firenze, Italy, August 25-31 1996), pp. 25-36.

Abraham,V.A., J.R. Faleiro, M.A. Al-Shuaibi and T. Prem Kumar. 2000. A strategy to manage red palm weevil Rhynchophorus ferrugineus Oliv. on date palm Phoenix dactylifera L. - Its successful implementation in Al-Hassa, Kingdom of Saudi Arabia, Pestology, 24: 23-30

Abraham, V.A., M.A. Al-Shuaibi, J.R. Faleiro, R.A. Abozuhairah and P.S.P.V. Vidyasagar. 1998. An integrated management approach for red palm weevil, Rhynchophorus ferrugineus Oliv., a key pest of date palm in the Middle East. Journal of Agricultural and Marine Sciences, 3: 77-83

https://doi.org/10.24200/jams.vol3iss1pp77-83

Al-Ayedh, H. 2008. Evaluation of date palm cultivars for rearing the red date palm weevil, Rhynchophorus ferrugineus (Coleoptera: Curculionidae). Florida Entomologist, 91: 353-358 https://doi.org/10.1653/00154040(2008)91[353:eodpcf]2.0.co;2

Al-Bagshi, M., A. Al-Shagag, S. Al-Saroj, S. Al-Bather, A. Al-Shawaf, A. Al-Dandan, Y. Al- Suleiman, E. Al-Abdallah and A. Abdallah. 2013. Oviposition 
preference of red palm weevil, Rhynchophorus ferrugineus (Olivier) (Coleoptera: Curculionidae) to date palm cultivars. Pest Management in Horticultural Ecosystems, 19: 108-112

Al-Dosary, N.M.N, S. Al-Dobai and J.R. Faleiro. 2016. Review on the management of red palm weevil Rhynchophorus ferrugineus Olivier in date palm Phoenix dactylifera L. Emirates Journal of Food and Agriculture, 28: 34-44 https://doi.org/10.9755/ejfa.2015-10-897

Anonymous. 2013. Save Algarve palms. http://www.savealgarvepalms.com/en/weevilfacts/host-palmtrees

Anonymous. 2006. The famous date varieties in the Kingdom of Saudi Arabia. Ministry of Agriculture, Kingdom of Saudi Arabia and Food and Agriculture Organization of the United Nations. 245 pp.

Ashraf, Z. and Z. Hamidi-Esfahani. 2011. Date and date processing: a review. Food Reviews International, 27: 101-133. http://dx.doi.org/10.1080/87559129.2010.535231

Avalos, J.A., A. Martí-Campoy and A. Soto. 2014. Study of the flying ability of Rhynchophorus ferrugineus (Coleoptera: Dryophthoridae) adults using a computermonitored flight mill. Bulletin of Entomological Research 104: 462-470 https://doi.org/10.1017/s0007485314000121

Dembilio, Ó. and J.A. Jaques. 2015. Biology and management of red palm weevil. In: Sustainable Pest Management in Date Palm: Current Status and Emerging Challenges. W. Wakil, J.R. Faleiro and T. Miller (eds.). Springer International Publishing. Switzerland, $445 \mathrm{p}$.

Dembilio, O. and J.A. Jacas. 2012. Bio-ecology and integrated management of the red palm weevil, Rhynchophorus ferrugineus (Coleoptera: Curculionidae), in the region of Valencia (Spain). Hellenic Plant Protection Journal, 5: 1-12.

Dembilio, Ó., J.M. Riba, M. Gamón and J.A. Jacas. 2015. Mobility and efficacy of abamectin and Imidacloprid against Rhynchophorus ferrugineus in Phoenix canariensis by different application methods. Pest Management Science, 71: 1091-1098 https://doi.org/10.1002/ps.3889

El-Sabea, A.M.R., J.R. Faleiro and M.M. Abo El Saad. 2009. The threat of red palm weevil Rhynchophorus ferrugineus to date plantations of the Gulf region of the Middle East: an economic perspective. Outlook on Pest Management, 20: 131-134. https://doi.org/10.1564/20jun11
El-Shafie, H.A.F. 2012. Review: List of arthropod pests and their natural enemies identified worldwide on date palm, Phoenix dactylifera L. Agriculture and Biology Journal of North America, 3: 516-524. http://www.doi:10.5251/abjana.20123.12516.524

FAOSTAT. 2016. Food and Agriculture Organization of the United Nations, Rome, Italy. Available from: http://faostat.fao.org/default.aspx

FAOSTAT. 2013. Food and Agricultural Commodities Production. Available from: http://www.faostat3.fao.org/download/Q/QC/E

Faleiro, J.R and A.M. Al-Shawaf. 2018. Management of Key Insect Pests of Date Palm. IPM of Red Palm Weevil. El Bouhssini, Mustapha, and Jose Romeno Faleiro. Date Palm Pests and Diseases Integrated Management Guide. Beirut, Lebanon: International Center for Agricultural Research in the Dry Areas (ICARDA), 2018.

Faleiro, J. R. 2006. A review of the issues and management of the red palm weevil, Rhynchophorus ferrugineus (Coleoptera: Rhynchophoridae) in coconut and date palm during the last one hundred years. International Journal of Tropical Insect Science, 26: 135-154 https://doi.org/10.1079/IJT2006113

Farazmand, H. 2002. Investigation on the reasons of food preference of red palm weevil, Rhynchophorus ferrugineus Oliv. Applied Entomology and Phytopathology, 70: 49-62

General Authority for Statistics, KSA 2015. Detailed results of the Agricultural Census. http://www.stats.gov.sa

Khalifa, O, A.H. El Assal, F.A.A. Ezaby, M.A. Murse, S.M. Al Nuaimi and N.S. Al-Zehli. 2001. Database for infestation of date palm by red palm weevil (Rhynchophorus ferrugineus Oliver). Pages 25-27. In: U.A.E. and Oman. $2^{\text {nd }}$ International Conference on Date Palms, Al-Ain, UAE.

Sallam, A.A., H.A.F. El-Shafie and S. Al-Abdan. 2012. Influence of farming practices on infestation by red palm weevil Rhynchophorus ferrugineus (Olivier) in date palm: A case study. International Research Journal of Agricultural Science and Soil Science, 2: 370-376.

UN comtrade. 2018. United Nations Commodity Trade Statistics Database- Int. trade Statistics. https://comtrade.un.org/db/

Vison. 2030. The government of Saudi Arabia. National transformation program. (Last accessed on 2019 January 03). Available from: http://www.vision2030.gov.sa/sites/default/files/NTP En.pdf 